Оригинални научни рад

УДК 811.161.1'373.612.2

811.163.41'373.612.2

$811.111^{\prime} 373.612 .2$

Примљен: 31. марта 2021.

Прихваћен: 6. маја 2021.

Емилија Г. Јовић ${ }^{1}$

https://doi.org/10.46630/phm.13.2021.50

Универзитет у Нишу

Филозофски факултет

Департман за руски језик и књижевност

\title{
УЛОГА ПОЈМОВНЕ МЕТАФОРЕ ПУТОВАҢА У ФРАЗЕОЛОГИЗАЦИЈИ ЛЕКСЕМЕ ПУТ НА ПЛАНУ РУСКОГ, СРПСКОГ И ЕНГЛЕСКОГ ЈЕЗИКА
}

У раду истражујемо основне принципе развијања појмовне метафоре ПУТОВАҢА на материјалу лексеме пут у саставу фразеолошких јединица у руском, српском и енглеском језику. Циљ нашег истраживања представља утврђивање сличности и разлика између анализираних метафоричних израза у сва три језика. Као теоријски оквир послужила нам је теорија појмовне метафоре и сликовних схема, док се методолошки ослањамо на контрастивни метод у анализи. Полазећи од претпоставке да је концептуализација појма пут врло слична у истраживаним језицима, утврдили смо да је највећи број ексцерпираних фразеолошких јединица у сва три језика у кореспондентном или еквивалентном односу.

Кључне речи: фразеологизми, појмовна метафора, пут, сликовне схеме, фразеолошка слика света, концептуална анализа

1. Увод

Предмет овог рада биће фразеологизми који у свом саставу имају лексему пут као део појмовне метафоре ЖИВОТ ЈЕ ПУТОВАҢЕ. Истраживање и контрастивна анализа фразеолошких јединица често је мултидисциплинарног карактера, те оставља простора и за когнитивно-лингвистички и културолошки приступ њиховом истраживању. Стога су циљеви нашег рада следећи:

- ексцерпирање фразеологизама у руском, српском и енглеском језику који садрже лексему пут, чија позадинска метафора је ЖИВОТ ЈЕ ПУТОВАњЕ;

- утврђивање сличности и разлика између анализираних мета1 emilija.jovic@filfak.ni.ac.rs 
форичних израза као начина концептуализовања стварности на основу одређених метафора.

Полазећи од претпоставке да је концептуализација појма пут (путовање) слична у сва три језика очекивани резултати би били висок ниво кореспонденције и сличности, мада би издвојени случајеви могли да указују на значајне разлике.

Когнитивни приступ метафори подразумева издвајање карактеристика процеса формирања нових концепата посредством облика једноставних и познатих појмова, као и изучавање универзалних и културолошки-специфичних закономерности 'појезичавања' света које се у скривеном облику налазе у метафорама. Овакав приступ метафоричној стварности довео је до стварања теорије појмовне метафоре која постаје један од најзаступљенијих метода концептуалне анализе у савременим когнитивним истраживањима (LEJKOF, DŽONSON 1980: 242). У нашем раду користимо управо овај метод при интерпретацији лексеме пут у саставу фразеологизама у руском, српском, и енглеском језику.

Сви примери фразеологизама (укупно 90) преузети су из општих и фразеолошких речника чији списак прилажемо на крају рада. Ради методолошке доследности, у раду ћемо паралелно користити појмове фразеологизам/фразеолошка јединица, према већ устаљеној методологији (MRŠEVIĆ-RADOVIĆ 1987: 5). У раду ћемо настојати да прикажемо начин на који се концептуализује стварност, оличена у фразеолошким конструкцијама.

Укупно 90 фразеологизама (почетни у анализи је руски језик, преводни еквиваленти су у српском и енглеском језику) је анализирано на основу сличности и разлика у значењу и форми. Коришћена је техника утврђивања сличности и разлика, а као tertium comparationis узета је фигуративна вредност израза. Стога рад дефинишемо као контрастивно, једносмерно и синхронијско истраживање. Методом узорковања (рус. сплошная выборка) на речничком корпусу чији главни и најзаступљенији део чине релевантни фразеолошки речници у истраживаним језицима покушали смо да укажемо на степен семантичке и лексичке подударности између фразеологизама са лексемом пут у руском, српском и енглеском језику. Примери фразеологизама бирани су на основу кључне речи пут у њиховом саставу.

\section{2. Теоријски оквир и претходна истраживања}

Метафора $^{2}$ се као многоаспектна језичка појава дуго и пажљиво изучава у лингвистици. Предмет истраживања биле су карактеристике формирања метафоричних израза у језику, обим и садржина појма мета2 Води порекло од грчке речи methapherein што значи "пренос“" [McGlone, 2007: 110]. 
форе, карактеристике језичких механизама који се налазе у основи метафоризације, културно-специфичне особености образовања метафоричних јединица, функције и структура метафоре и сл (LEJKOF, DŽONSON 1980; McGlone 2007).

У савременој лингвистици истраживања метафоре су добила своју когнитивну усмереност. У светлу датих научних представа о језику метафора је виђена не само као језичка појава, већ и као средство концептуализације стварности, као гносеолошки механизам и средство одраза нових сазнања у језику (LEJKOF, DŽONSON 1980: 56). Пажња је, тачније, усмерена на улогу моделирања коју метафора има. Аутор Арутјунова истиче да „метафора не само да формира представу о неком објекту, већ одређује и начин мишљења и перцепције тог објекта" (ARUTJUNOVA 1999: 896).

Теорија појмовне метафоре подразумева представљање једне апстрактне и мање познате области кроз другу, емпиријски истраженију, познатију и доступнију област (LEJKOF, JOHANSON 1980). На тај начин се постиже пројекција знања са једне концептуалне области на другу путем метафоричног преноса значења (KUBRJAKOVA 1988: 141-172).

Према интеракционом приступу обраде метафоре појмовна метафора се као спознајна способност одражава у језику и има своја два нивоа: метафорички језички израз и концептуалну метафору (STANOJEVIĆ 2009: 339 - 340). Тако метафора обухвата основни субјекат метафоре, метафоризатор, тј. њен помоћни субјекат, нека својства основног субјекта и нека својства помоћног субјекта. Она настаје путем „предикције карактеристика помоћног субјекта основном субјекту” (APRESJAN 1993: 357). Ове карактеристике нису увек суштинске - метафора настаје на основу асоцијација које представљају културно-историјску појаву, услед које се оне разликују не само код различитих народа и језика, већ и у оквиру једне исте нације и говорног подручја. У случајевима када се асоцијације поклапају, могуће је и слагање метафора и њихова истоветна интерпретација. Значење сваке метафоричке јединице, укључујући и фразеолошке, првобитно је мотивисано својствима метафоризатора који је познат носиоцима дате језичке културе (LEJKOF 1999: 624).

Улога метафоре у процесу фразеологизације је неједнака: код различитих типова фразеологизама које издваја В. В. Виноградов (VINOGRADOV 1977: 140 - 161) она доводи до неједнаког степена идиоматичности њихових значења. Тако први степен идиоматизације слободних израза формира фразеолошке изразе. Њихово значење је резултат делимичне трансформације, тј. развоја значења једне од лексичких компонената где су смер и резултати тог развоја условљени многозначношћу дате лексичке јединице. Како се веза значења вишезначне речи 
може представити у виду семантичке мреже која суштински представља „материјал који се памти и конструише” (RAHILINA 2000: 415) значење изнова образоване фразеолошке јединице је такође мотивисано. Као пример наводимо однос између следећа три израза у истраживаним језицима: счастливого пути - срећан пут - have a nice trip. Основна нит ових израза своди се на концепт срећног почетка пута или неке друге активности.

У фразеолошким јединицама једна компонента иступа у свом директном слободном значењу, док се друга компонента употребљава у везаном, зависном значењу које није у потпуности самостално. Такви су фразеологизми у руском и српском језику найти путь к сердцу - наћи пут до срца. Дакле, компонента срце је та која утиче на преосмишљавање израза наћи пут. Тако се ограничење слагања различитих компоненти односи и на губитак првобитних деривационих веза. У нашем случају лексема пут у саставу следећих фразеологизама мења везу глагола давати са објектом: давать дорогу - ослобађати пут (некоме) где је веза са мотивском речју и смислом 'давања нечега' изгубљена.

На тај начин се почетни процес фразеологизације карактерише трансформацијом интенсионала првобитног (језичког) значења неког лексичког компонента и актуелизацијом његовог импликационала, тј. оних особина које одражавају устаљене асоцијације повезане са помоћним субјектом метафоре, у чему је и њена улога у образовању фразеолошке јединице у целости.

Други степен фразеологизације која је у различитим језицима представљена фразеолошким јединством подразумева да се улога метафоре повећава. Јединства „представљају устаљења праћења живих, сликовитих израза који су слободно груписани око неког метафоричног центра" (VINOGRADOV 1977: 155). То су, дакле, речи које су подчињене јединству општег израза или јединству реалног значења, што за резултат има целовито, недељиво значење које потиче од слагања лексичких компонената, а у исто време је и до неког степена независно. Дата парадоксалност њихове семантике објашњава се тиме што је денотат фразеолошког јединства заправо ситуација - реална или хипотетичка. У процесу образовања тог јединства одражава се и наша способност да мислимо о једној менталној области кроз призму друге и да закључујемо исто. У нашем раду покушавамо да укажемо на јединства која повезују лексему пут са различитим културошким и лингвистичким цртама руског, српског и енглеског језика.

У литератури која покрива област когнитивне лингвистике српског језика од посебног значаја су радови ауторки Рајне Драгићевић, Драгане Мршевић-Радовић, Душке Кликовац. Потоња у књизи Метафоре у 
мишљењу и језику истиче да је значење језичких појава „утеловљено”, тј. да извире из нашег чулног и телесног искуства, затим да се препојмовни обрасци телесног искуства - сликовне схеме - механизми метафоре и метонимије преносе у нечулне, апстрактне домене, те тако разумевање језика укључује ментално сликовно представљање (KLIKOVAC 2004: 33).

Када говоримо о термину сликовних схема у првом реду имамо у виду ауторе попут Марка Џонсона, Тода Оуклија, Џ. Мандлера и др. Нагласак унутар когнитивне лингвистике на овој концептуалној димензији сугерише став у којем метафора у основи није лингвистички феномен. Заправо, когнитивни лингвисти метафору схватају као обрасце мишљења који се могу изразити на невербалне начине, попут слика и геста. Тако Тод Оукли сликовне схеме види као фиксне обрасце који се преклапају са перцепцијама и концепцијама да би пружили смислене представе (OUKLI 2007: 215). Поред тога, овај аутор наглашава њихову заснованост на просторном искуству.

У књизи The Body in the Mind: The Bodily Basis of Meaning, Imagination, and Reason аутор Марк Џонсон такође истиче да нам је за објашњавање тога како одређене метафоричне пројекције ограничавају значење односа и образаца закључивања, потребно да истражимо структуру сликовних схема на којима се заснивају, као и да морамо да утврдимо зашто се одређена мапирања изворних домена на циљне домене догађају онако како се догађају (DŽONSON 1987: 113). Џонсон такође дефинише и схему путање (пута) која је у нашем истраживању од кључне важности. Наш живот је испуњен путањама које повезују наш просторни свет. Површина ових путања укључује стварну физичку површину коју прелазимо, као што је нпр. пут од наше куће до продавнице. Друге површине укључују пројектовану путању, попут путање метка који је испаљен у ваздух, док одређени путеви тренутно постоје само у нашој машти, попут путање од Земље до најближе звезде изван нашег Сунчевог система. У свим овим случајевима постоји један, понављајући шематски образац слике са дефинисаном унутрашњом структуром. У сваком случају ПУТА постоје увек исти делови: (1) извор или полазна тачка, (2) циљ или крајња тачка и (3) низ суседних локација које повезују извор са циљем. Путање су тако руте за кретање од једне до друге тачке (DŽONSON 1987: 113).

Џорџ Лејкоф и Марк Џонсон издвајају три основна типа метафоре које одражавају устаљена и стабилна слагања у колективном сазнању носилаца једног језика и културе:

а) структурне метафоре - описивање једне појаве терминима друге;

б) оријентационе метафоре - концепти се структуришу путем 
просторних односа и

в) онтолошке метафоре - дозвољавају представљање апстрактних појава у виду материјалних супстанци (LEJKOF, DŽONSON 2004: 137).

Један од истакнутијих истраживача, када је реч о метафорама и метонимији, свакако је Золтан Кевечеш који циљни домен дефинише као „домен који покушавамо да разумемо коришћењем изворног домена“ (KEVEČEŠ 2010: 4). За разлику од интеракционог приступа, овде се наглашава онај који је заснован на појмовним пресликавањима. Он такође тврди да „најчешћи изворни домени за метафорична пресликавања укључују домене који се односе на људско тело“. Рад Мајкла Редија The Conduit Metaphor показао је да је фокус метафоре мишљење, а не језик, те да је метафора велики и витални део нашег начина концептуализације света и да наше свакодневно понашање одражава наше метафорично разумевање искуства.

Лејкоф такође наводи да „уопштавања која управљају метафоричким изразима нису у језику, већ у мислима: то су општа мапирања појмовних домена“ (LEJKOF 2004: 1). То значи да се фокус метафоре налази у начину концептуализације једног менталног домена кроз други. Темељ теорије појмовне метафоре лежи, дакле, у карактеризацији пресликавања различитих домена. Тако је метафора постала модел мапирања домена у концептуалном систему.

Мапирање се односи на „систематске метафоричке кореспонденције између блиско повезаних идеја“ (GREJDI 2007: 190). Језик и слике које пружа изворни домен метафоре користе се за упућивање на циљни домен. На пример, курс брода може представљати изворни домен, а државна политика може представљати циљни домен. Дакле, кретање брода „пресликава се“ на ток политичког напретка државе.

Веома чест пример концептуалног мапирања ЉУБАВ JЕ ПУТОВАњЕ користиће се да покаже да су метафоре мапирања или скупови концептуалних подударности. Знање о путовању може се пресликати на знање о љубави. То нам омогућава да љубав схватимо кроз знање о путовањима у реченицама као што су:

„Они су на раскршћу у свом односу.“

„Ова веза не води никуда.“

„Они су у ћорсокаку“ (LEJKOF, ESPENSON i dr 1991: 153).

Постоје различити метафорички обрасци који укључују вишеструку кореспонденцију између изворних и циљних домена. На пример, ЖИВОТ JЕ ПУТОВАҢЕ може се сматрати ширим обрасцем у поређењу са обрасцем ЉУБАВ ЈЕ ПУТОВАҢЕ. Према томе, „метафоре постоје у хијерархијама специфичности, у којима се може рећи да одређенији образац наслеђује општији“ (GREJDI 2007: 191). 
„Метафорична мапирања чувају когнитивну топологију (односно структуру слике-шеме) изворног домена, на начин који је у складу са инхерентном структуром циљног домена“" (LEJKOF 1992: 10).

И на крају, постоје два типа мапирања: концептуално мапирање и мапирање слика-шема. Лејкоф описује конвенционални концептуални систем метафора као углавном несвестан и аутоматски, употребљен без значајних напора, баш као и наш језички систем и остатак нашег концептуалног система. Конвенционални систем метафора непрестано се користи аутоматски и подсвесно. Разумевање искустава и начин на који мислимо и делујемо на основу тога ослања се на наш систем метафора. Уобичајена пресликавања су статичне кореспонденције које се не ослањају на скуп правила. Метафора обично користи кореспонденције у нашим искуствима, а не сличности и има своје место и у граматици и у лексици једног језика.

Метафоре које су нама послужиле за анализу и класификацију примера из истраживаних језика су следеће: ЖИВОТ ЈЕ ПУТОВАҢЕ, ЉУБАВ ЈЕ ПУТОВАҢЕ, ПУТ ЈЕ ТРАГАҢЕ, ЖИВОТ ЈЕ БОРБА, ПУТ ЈЕ МИШЉЕЊЕ, ПУТ ЈЕ РАЗВОЈ и ПУТ ЈЕ ЗАБЛУДА. Ове метафоре су извор различитих метафоричних израза које у свом саставу имају лексему пут.

\section{1 Пут као лексички концепт у руском, српском и енглеском језику}

Читав низ концепата својствених човековој стварности метафоризује се на основу пута као полазне области у сагледавању ширег концепта „кретања по путу”. Оно што обједињује значења ове лексеме у сва три језика јесте управо појам и нека врста кретања (човека, мисли, робе, информација итд.). Како је лексема пут неретко компонента фразеолошких јединица које, пак, одражавају специфичне елементе једне културе и језика, покушаћемо да укажемо на најупечатљивије механизме концептуализације метафора које обухватају ову лексему у руском, српском и енглеском језику.

Ослањајући се на постојеће речничке дефиниције $\mathrm{e}^{3}$ лексема дорога (путь), пут и trip издвајамо следећа значења:

Дорога - у руском језику само постојање две засебне лексеме указује на могуће разлике у значењима:

a) полоса земли, предназначенная для передвижения, наземный путь сообщения;

б) рельсовый путь для движения поездов;

в) транспортное предприятие, комплекс сооружений, технических

3 Попис консултованих речника видети у попису литературе и извора. 
средств и служб, занимающихся перевозкой пассажиров и грузов по рельсовым путям;

г) направление деятельности, образ действий, ход жизни;

д) направление, путь, по к-рому можно идти, двигаться.

Када говоримо о лексеми путь у руском језику у речнику бележимо следећа значења:

\section{Путь}

1. Полоса земли, служащая для передвижения (езды и ходьбы); дорога.

2. обычно мн.: пути, -ей. Железнодорожная или трамвайная колея, линия;

3. Пространство, по которому осуществляется транспортное сообщение;

4. Место для прохода, проезда куда-л;

5. Расстояние, которое проходит или проезжает кто-л;

6. только мн.: пути, -ей. Анат. Орган в виде канала, в котором совершается какая-л. деятельность;

7. Передвижение куда-л.; поездка, путешествие;

8. Направление движения, маршрут;

9. Направление деятельности, развития кого-, чего-л;

10. Средство, способ достижения чего-л;

11. Жизнь человека, её течение.

У Речнику Матице српске, као и Речнику српскохрватског књижевног језика лексема пут одређена је на следећи начин:

12. дуги и уски део земле у облику траке који служи заходање и уопште кретање, цеста;

13. место, земљиште којим треба проћи, пролаз;

14. (обично у вези с атрибутом: гвоздени) железнички колосек, пруга;

15. (обично мн.) анат. орган у облику канала којим се врши каква физиолошка функција;

16. кретање куда даље од сталног боравишта с каквим циљем (ради свршавања каквог посла, ради забаве, упознавања или проучавања, спорта и сл.);

17. правац кретања. (RMS 2011).

У енглеском језику бележимо следеће лексеме које се у датом значењу могу сматрати синонимима ${ }^{4}$ :

4 У истраживаном речничком материјалу у енглеском језику бележимо само ових 7 
1. journey - an act of travelling from one place to another, especially when they are far apart;

2. motion - the act or process of moving or the way something moves;

3. path - a way or track that is built or is made by the action of people walking;

4. road - a hard surface built for vehicles to travel on;

5. trip - a journey to a place and back again, especially a short one for pleasure or a particular purpose;

6. voyage - a long journey, especially by sea or in space;

7. way - a route or road that you take in order to reach a place.

Оно што се на први поглед може уочити из наведених речничких дефиниција јесте да се основна значења све три лексеме у поменута три језика поклапају када имамо у виду кретање као уопштену радњу. Нпр. следећа значења лексеме пут у истраживаним језицима су идентична: полоса земли, предназначенная для передвижения, наземный путь сообщения/ дуги и уски део земле у облику траке који служи заходање и уопште кретање, цеста и path - a way or track that is built or is made by the action of people walking.

\section{3. Анализа фразеологизама са лексемом пут}

Концептуалну анализу у нашем раду извршили смо на материјалу фразеологизама ексцерпираних из релевантних фразеолошких речника сва три језика. Дати фразеолошки материјал убедљиво потврђује да „језик није само помоћни, већ понекад $u$ довољан инструмент који подупире мисаоне активности". Језик и мисли се развијају паралелно и усаглашено при чему надјезичка когнитивна структура и елементи који је симболишу образују нераскидиво јединство (KIBRIK 2015: 29-57).

У нашем раду поређењем три групе примера издвојили смо следеће појмовне метафоре:

\section{1. ЖИВОТ ЈЕ ПУТОВАњЕ}

Одраз ове метафоре у фразеологизмима са лексемом пут представљен је следећим примерима у сва три језика:

Все дороги открыты; Выводить на дорогу; Выходить на дорогу; Грудью пролагать себе дорогу; Дорога жизни; Идти своей дорогой; На дороге не валяется; На дорогу; Найти свою дорогу в жизни; На ложной дороге; Одна дорога; Перебегать дорогу; Переходить дорогу; Прегражда-

синонимичних лексема. Поред њих у употреби су и речи trail, track, route, line, као и многе друге. 
ть дорогу; Проложить дорогу; Останавливаться на полпути; Пойти своим путем; Пойти прамым путем/ Бити на кривом путу; Извести (изводити) [некога] на прави пут; Ићи (поћи) кривим (рђавим, лошим) путем; Ићи својим путем;/ an open path in life; the beaten path (track); follow the straight and narrow path; follow one's path; (to be) put on the right path; make way in life;

Схватање живота као пута (путовања) ослања се на концепцију кретања из једног места ка другом, из једног стања ка неком вишем или на достизање неког животног циља, што је засновано на просторном искуству и евидентно у сликовној схеми путање која представља основу процеса метафоризације значења. На том путу сусрећемо се са препрекама, потешкоћама, често скренемо са пута, или пронађемо прави пут што илуструју примери Пойти прямым путем/Бити на правом (кривом) путу; follow the straight and narrow path, који су и еквивалентни у сва три језика.

Примери Идти своей дорогой, Ићи својим путем и follow one's path такође као еквиваленти указују на пут као самостални избор у животу.

Почевши од прве издвојене метафоре ЖИВОТ ЈЕ ПУТОВАЮЕ на плану истраживаних језика уочавамо односе који ће бити најзаступљенији. Када је реч о еквивалентном односу код ове прве метафоре истичемо пар примера: все дороги открыты у руском језику нема свој еквивалент у српском, док му у енглеском језику одговарају изрази an open path in life; all roads/doors/paths are open. У кореспондентном односу стоје нпр. изрази идти своей дорогой/ићи својим путем/follow one's path. Пример непоклапања је фразеологизам грудью пролагать себе дорогу у руском језику.

\section{2. ЉУБАВ ЈЕ ПУТОВАҢЕ}

Из ове метафоре проистичу изрази Находить дорогу к сердцу, Найти путь к сердиу, Наћи пут до сриа и found the place in someone's heart, где у примеру на енглеском језику лексему пут замењује лексема место. Нова проширења конвенционалних метафора су веома занимљива. Наиме, текст песме We're driving in the fast lane on the freeway of love лако могу да разумеју изворни говорници енглеског језика захваљујући овој могућности. С обзиром на већ постојеће метафорично мапирање ЉУБАВ JЕ ПУТОВАҢЕ, које је већ део нашег концептуалног система, постоји могућност да се нова проширења разумеју у смислу наших конвенционалних кореспонденција (LEJKOF 2004).

Метафора ЉУБАВ ЈЕ ПУТОВАЮЕ илуструје еквивалентни однос између истраживаних језика, с обзиром на то да у енглеском језику бележимо разлику у једној лексичкој компоненти: найти дорогу к сердцу/ 
наћи пут до срца/found the place in someone's heart.

\section{3. ПУТ ЈЕ ТРАГАҢЕ}

Метафора која указује на процес трагања за нечим и достизања/недостизања до коначног циља представљена је следећим изразима: Выбиваться на (широкую) дорогу, Выходить на дорогу, Грудью пролагать себе дорогу, Заступать дорогу Найти свою дорогу в жизни, Открывать дорогу, Столбовая дорога, Пойти по пути наименьшего сопротивления. У српском језику не налазимо еквиваленте, док у енглеском језику бележимо примере come to the end of an earthly journey, go back on the right path; return to the path of truth.

Трећа издвојена метафора ПУТ ЈЕ ТРАГАҢЕ нема своју пројекцију у фразеологизмима у српском језику. Као еквиваленте истичемо примере наставить на путь истинный у руском језику и return to the path of truth у енглеском језику.

\section{4. ПУТ ЈЕ БОРБА}

Примери Избитая дорога, Катись своей дорогой, На дороге не валяется, Останавливаться на полдороге, Становиться поперек дороги, Сходить с дороги, Сбиться с пути, Стоять на пути, Стати (остати) на пола пута, evil ways, make way in life, make way for someone, halfway, midway илуструју живот као непрестану борбу.

Кореспондентни однос између фразеологизама у руском, српском и енглеском језику илуструје метафора ПУТ ЈЕ БОРБА: сходить с дороги/скренути са пута $u$ set out on the path.

\section{5. ПУТ ЈЕ МИШЉЕЊЕ}

Примери фразеологизама из ове групе осим физичког раздвајања могу указивати и на оно по питању мишљења или ставова. Дакле, бити на истом путу = имати исто мишљење/став: Дороги разошлись, Уступать дорогу, Пути разошлись, Путеви су нам се разишли, our ways parted; our paths diverged, и они су еквивалентни у истраживаним језицима.

Метафором ПУТ ЈЕ МИШЉЕЊЕ обухваћени су примери фразеологизама које сврставамо у кореспондентне: дороги разошлись/путеви су нам се разишли/ our ways parted; our paths diverged.

\section{6. ПУТ ЈЕ РАЗВОЈ}

У руском језику бележимо и примере који су обједињени фигуративним значењем развитка или успеха до кога се долази на неком путу: 
Дорогу осилит идущий; На распутье; Путь наименьшего сопротивления, Пойти по привычной дорожке.

Примери као што су путь наименьшего сопротивления/пут којим ce peђе иде и take the road less traveled чија позадина је метафора ПУТ ЈЕ РАЗВОЈ спадају у кореспондентне фразеолошке изразе.

\section{7. ПУТ КАО ЗАБЛУДА}

Јединствени пример у руском језику је фразеологизам Пути ясны, да очи слепы својом садржином указује на заслепљеност, заблуду у току неког пута, животног најчешће. Еквиваленти у српском и енглеском језику изостају. Као могући фразеолошки израз у енглеском језику наводимо to hit a dead and street.

Метафора ПУТ ЈЕ ЗАБЛУДА своју фразеолошку реализацију има само у руском језику, у примеру пути ясны, да очи слепы.

Како бисмо резултате нашег истраживања приказали у кључу њиховог преводног еквивалента, у Табели 1 дајемо преглед ексцерпираних фразеолошких израза. Највише примера илуструје кореспондентни, затим еквивалентни и на крају однос који подразумева непоклапање на плану истраживаних језика.

\begin{tabular}{|c|c|c|c|c|}
\hline Метафора & Руски језик & Српски језик & Енглески језик & $\begin{array}{l}\text { Тип преводног } \\
\text { еквивалента }\end{array}$ \\
\hline \multirow{5}{*}{$\begin{array}{l}\text { 1. ЖИВОТ ЈЕ } \\
\text { ПУТОВАЬЕ }\end{array}$} & Все дороги открыты; & & $\begin{array}{l}\text { an open path in life; } \\
\text { all roads/doors/paths } \\
\text { are open; }\end{array}$ & еквиваленција \\
\hline & $\begin{array}{l}\text { Выводить на дорогу; } \\
\text { Выходить на дорогу; }\end{array}$ & $\begin{array}{l}\text { Извести (изводити) } \\
\text { [некога] на прави } \\
\text { пут; }\end{array}$ & $\begin{array}{l}\text { puth on the right path; } \\
\text { put on the right path; } \\
\text { make way in life; make } \\
\text { way for someone; }\end{array}$ & кореспонденција \\
\hline & $\begin{array}{l}\text { Грудью пролагать } \\
\text { себе дорогу; }\end{array}$ & & & непоклапање \\
\hline & $\begin{array}{l}\text { Давать дорогу; } \\
\text { Дорога жизни; }\end{array}$ & Животни пуг; & & еквиваленција \\
\hline & $\begin{array}{l}\text { Идти своей дорогой; } \\
\text { Катись своей } \\
\text { дорогой; Пойти } \\
\text { своим путем; Пойти } \\
\text { прамым путем; } \\
\text { Найти свою дорогу в } \\
\text { жизни; }\end{array}$ & $\begin{array}{l}\text { ИҺи (поһи) кривим } \\
\text { (рђавим, пошим) } \\
\text { путем; Иһи својим } \\
\text { путем; Бити на } \\
\text { кривом пугу; }\end{array}$ & $\begin{array}{l}\text { follow the straight and } \\
\text { narrow path; follow } \\
\text { own path; }\end{array}$ & кореспонденција \\
\hline
\end{tabular}


5

\begin{tabular}{|c|c|c|c|c|}
\hline & $\begin{array}{l}\text { На дороге не } \\
\text { валяется; На дорогу; } \\
\text { На ложной дороге; } \\
\text { Одна дорога; }\end{array}$ & & $\begin{array}{l}\text { along the way; en } \\
\text { route; on the voyage } \\
\text { on a path leading to; } \\
\text { on the road to; for the } \\
\text { trip; for the road; on } \\
\text { the trip; on the road; }\end{array}$ & еквиваленција \\
\hline & $\begin{array}{l}\text { Перебегать } \\
\text { дорогу Переходить } \\
\text { дорогу; Преграждать } \\
\text { дорогу; Проложить } \\
\text { дорогу; }\end{array}$ & & $\begin{array}{l}\text { come to the end of } \\
\text { earthly journey; }\end{array}$ & еквиваленција \\
\hline & $\begin{array}{l}\text { Останавливаться на } \\
\text { полпуги; } \\
\text { Останавпиваться на } \\
\text { полдороге; }\end{array}$ & $\begin{array}{l}\text { Стати (остати) на } \\
\text { пола пуга; }\end{array}$ & halfway; midway; & кореспонденција \\
\hline $\begin{array}{l}\text { 2. ЉУБАВ ЈЕ } \\
\text { ПУТОВАҢЕ }\end{array}$ & $\begin{array}{l}\text { Находить дорогу к } \\
\text { сердцу; Найти путь к } \\
\text { сердцу; }\end{array}$ & Наһи пут до срца; & $\begin{array}{l}\text { found the place in } \\
\text { someone's heart; }\end{array}$ & кореспонденција \\
\hline 3. ПУТ ЈЕ ТРАГАЮЕ & $\begin{array}{l}\text { Выбиваться на } \\
\text { (широкую) дорогу; } \\
\text { Выходить на дорогу; } \\
\text { Заступать дорогу; } \\
\text { Найти свою дорогу в } \\
\text { жизни; Наставить на } \\
\text { путь } \\
\text { истинный;Открывать } \\
\text { дорогу; Столбовая } \\
\text { дорога }\end{array}$ & & $\begin{array}{l}\text { go back on the right } \\
\text { path; return to the } \\
\text { path of truth; }\end{array}$ & еквиваленција \\
\hline
\end{tabular}

5 Тип односа између анализираних фразеологизама установљен је на релацији рускисрпски и руски-енглески, са нагласком на кључној речи пут у анализи. 


\begin{tabular}{|c|c|c|c|c|}
\hline 4. ПУТ ЈЕ БОРБА & $\begin{array}{l}\text { Избитая дорога; На } \\
\text { дороге не валяется; } \\
\text { Становиться поперек } \\
\text { дороги; Сбивать с } \\
\text { пути (кого-то); } \\
\text { Сбиться с пути; } \\
\text { Сходить с дороги; } \\
\text { Сбиться с пути; } \\
\text { Стоять на пути; }\end{array}$ & Скренути са пута; & set out on the path; & кореспонденција \\
\hline $\begin{array}{l}\text { 5. ПУТ ЈЕ } \\
\text { МИПІЬЕЬЕ }\end{array}$ & $\begin{array}{l}\text { Дороги разошлись; } \\
\text { Уступать дорогу; } \\
\text { Пути разошлись; }\end{array}$ & $\begin{array}{l}\text { Путеви су нам се } \\
\text { разишли; }\end{array}$ & $\begin{array}{l}\text { our ways parted; our } \\
\text { paths diverged; }\end{array}$ & кореспонденција \\
\hline 6. ПУТ ЈЕ РАЗВОЈ & $\begin{array}{l}\text { Дорогу осилит } \\
\text { идущий; } \\
\text { Путь наименьшего } \\
\text { сопротивления; } \\
\text { Пойти по привычной } \\
\text { дорожке; }\end{array}$ & $\begin{array}{l}\text { Пут којим се pebe } \\
\text { иде }\end{array}$ & $\begin{array}{l}\text { the beaten track path; } \\
\text { the well-worn path; } \\
\text { stay of the beaten track } \\
\text { path; take the road less } \\
\text { traveled; }\end{array}$ & кореспонденција \\
\hline 7. ПУТ ЈЕ ЗАБЛУДА & $\begin{array}{l}\text { Пути ясны, да очи } \\
\text { слепы }\end{array}$ & & & непоклапане \\
\hline
\end{tabular}

Табела 1. Приказ фразеологизама

3.1. Дискусија

На основу прикупљене грађе, утврђено је да превагу свакако односе еквивалентни фразеолошки изрази у руском, српском и енглеском језику. У раду смо настојали да, на основу прикупљених фразеолошких јединица укажемо на појмовне метафоре око којих су сконцентрисани фразеологизми који садрже лексему пут. Све ове фразеологизме могли бисмо класификовати у неколико група у зависности од тога на који метафорични центар (јединство) указују: самосталност, препрека, међусобна активност, немогућност достизања неког циља, и супротно, достизање циља итд. Сва ова значења укључују неку врсту кретања, физичког или апстрактног, што је опет у вези повезано са сликовним схемама.

На основу ексцерпираног материјала (укупно 90 фразеологизама у сва три језика) на тренутном нивоу истраживања дате теме можемо да закључимо следеће:

1. у сва три језика постоје издвојене фразеолошке јединице које немају своје еквиваленте у остала два језика: рус. Бог по дороге, а черт стороной, Грудью пролагать себе дорогу, Романитики с большой дороги, Наставить на путь истинный; срп. Пут за уши!; Пут под ноге! и be a self-made man/woman у енглеском језику који се посебно издваја због тога што се значење „самосталности на животном путу" подвлачи управо употребом именица човек/ жена; 
2. појмовна метафора у руском језику најизраженија је у примерима са лексемом путь где се фразеолошко значење формира на основу асоцијације са „животним путовањем, животом као трајањем";

3. у српском језику постојање фразеологизама који стилски припадају вулгаризмима упућује на разговорни карактер који метафору не ставља у први план, али подвлачи оправданост употребе ових лексичких јединица у свакодневном говору;

4. фразеологизам В добрый путь у руском језику који метафорички указује на „жељу за успешним почетком нечега” у српском језику има еквивалент у изразу „У добри час” који у себи нема компоненту пута, док у енглеском језику ово значење покривају идиоми good speed to you, good luck.

5. на основу анализираних примера фразеологизама са лексемом пут у руском, српском и енглеском језику закључујемо да се највећи део њих може сврстати у структурне и оријентационе метафоре.

Анализа метафоричних значења у фразеологизмима са лексемом пут у руском, српском и енглеском језику показала је да ће превагу свакако однети сличности које су приметне на плану словенских језика, а да су уочене разлике битни фрагменти појединачних лингвокултуролошких и фразеолошких слика сваког од поменутих језика.

Издвојене фразеолошке јединице у датим језицима због природе своје блискости и етимолошких и семантичких сличности у највећем броју случајева имају исту или сличну метафоричну подлогу. Ипак, разлике које смо уочили говоре о различитим правцима развоја и удела у настанку појединачних фразеолошких израза. Тако на пример, фразеологизам Скатертью дорога у руском језику указује на жељу да се неко удаљи из ваше близине, да оде куда год било. Еквивалент у српском језику је израз Широко му (ти, јој, им) поље. У истом значењу у српском језику користи се и фразеологизам Пут под ноге ${ }^{6}$ чија позадина у већој мери указује на физички одлазак са неког места. У руском језику бележимо синонимичне изразе В добрый путь и В добрый час, којима у српском језику одговара израз Срећно или Са срећом. Фразеологизам Туда и дорога са негативном конотацијом у руском језику нема потпуне еквиваленте у српском и енглеском језику, али описно на српски језик може пренети изразом „тамо је и место [некоме]”, што је у вези са значењем оријентационих метафора где се просторне карактеристике одражавају на значење неког идиома. Фразеологизам библијског порекла Благими намерениями

6 Примери Пут под ноге и Пут за уши су истовремено и соматски фразеологизми. 
вымощена дорога в ад у руском језику и Пут до пакла поплочан је добрим намерама у српском језику немају своје еквиваленте у енглеском језику. Још једна одлика фразеологизама са лексемом пут у енглеском језику јесте да се у највећем броју случајева значењем и самом радњом упућује на прво лице или друго лице једнине (ми, ти), док је у руском и српском језику таква реализација покривена значењем инфинитива и безличних конструкција.

\section{4. Закључак}

У раду смо истраживали појмовну метафору ПУТОВАњА на материјалу фразеолошких јединица које садрже лексему пут у руском, српском и енглеском језику. База примера ових специфичних лексичких јединица оформљена је на основу ексцерпирања из фразеолошких и општих речника истраживаних језика (укупно 90 фразеологизама) и то на основу кључне речи пут. Како је наша полазна теза била та да се концептуализација појма пут слично реализује у сва три језика, а ослоњени на теорију појмовне метафоре која је подлога бројних метафоричних израза, као и метафоричко проширење сликовних схема као једне од главних поставки когнитивне лингвистике, анализом смо утврдили следеће:

- примери фразеологизама са лексемом пут у највећем броју случајева у истраживаним језицима стоје у кореспондентном односу (идти своей дорогой/ићи својим путем/ follow own path, сходить с дороги/скренути са пута и set out on the path, путь наименьшего сопротивления/пут којим се ређе иде и take the road less traveled);

- еквивалентни однос који најчешће подразумева изостанак фразеолошке јединице у неком од истраживаних језика је други по бројности (все дороги открыты, an open path in life; all roads/doors/paths are open, найти дорогу к сердиу/наћи пут до срца/found the place in someone's heart);

- непоклапања која су у теорији контрастивне анализе у ствари примери разлика између анализираних језичких, тј. фразеолошких слика света у нашем истраживању малобројна су, и подразумевају одсуство фразеолошких јединица у српском, тј. енглеском језику (грудью пролагать себе дорогу, пути ясны, да очи слепы).

На тренутном нивоу истраживања појмовне метафоре, као полазне основе за даља и обимнија проучавања фразеолошких јединица у трима језицима, налазимо као битну чињеницу да је могуће поредити три различите фразеолошке и метафоричне слике управо захваљујући фигуративном значењу које представља својеврстан надкриљујући елемент у контрастирању датих лексичких јединица. На плану словенских језика свакако су приметније сличности, мада и уочене разлике у релацији са енглеским језиком дају основа за будућа шира контрастивна проучавања 
ове тематике.

\section{Цитирана литература}

APRESJAN 1993: APRESJAN, Jurij Derenikovič. Metafora $v$ semantičeskom predstavlenii emocij. Izdatelstvo RAN, Voprosi jazikoznanija Moskva: 1993. [orig] АПРЕСЯН, Юрий Дереникович. Метафора в семантическом представлении эмоиий. Издательство РАН, Вопросы языкознания Москва: 1993.

ARUTJUNOVA 1999: ARUTJUNOVA, Nina Davidovna. Jazik i mir čeloveka. Jaziki ruskoj kulturi. Moskva: 1999. [orig] АРУТЮНОВА, Нина Давидовна. Язык и мир человека. Языки русской культуры. Москва: 1999.

VINOGRADOV 1977: VINOGRADOV, Viktor Vladimirovič. Ob osnovnih tipah frazeologičeskih jedinic v ruskom jazike. Nauka. Moskva: 1977. [orig] ВИНОГРАДОВ, Виктор Владимирович. Об основных типах фразеологических единиц в русском языке. Наука. Москва: 1977.

GREJDI 2007: GRADY, Joseph. Metaphor. in: The Oxford Handbook of Cognitive Linguistics, Geeraerts D., Cuyckens H. (eds.), 188-194. Oxford University Press.4 New York: 2007.

DRAGIĆEVIĆ 2007: DRAGIĆEVIĆ, Rajna. Leksikologija srpskog jezika. Zavod za udžbenike. Beograd: 2007.

ĐORĐEVIĆ 1982: ĐORĐEVIĆ, Radmila. Uvod u kontrastiranje jezika. BU Filološki fakultet. Beograd: 1982.

KIBRIK 2015: KIBRIK, Aleksandar Jevgenjevič. Kognitivni podhod k jaziku. Jaziki slovjanskoj kulturi. Moskva: 2015. [orig] КИБРИК, Александр Евгеньевич. Когнитивный подход к языку. Языки словянской культуры. Москва: 2015.

KEVEČEŠ 2010: KÖVECSES, Zoltan. Metaphor: A Practical Introduction. 2nd edition. Oxford University Press. Oxford: 2010.

KLIKOVAC 2004: KLIKOVAC, Duška. Metafore u mišljenju i jeziku. Biblioteka XX vek. Beograd: 2004. [orig] КЛИКОВАЦ, Душка. Метафоре у мишљеюьу и језику. Библиотека XX век. Београд: 2004.

LEJKOF, DŽONSON 2004: LAKOFF, George. Metaphors We Live By. Basic Books. NY: 2004.

LEJKOF, ESPENSON i dr. 1991: LAKOF George., ESPENSON J., and Schwartz A. Master Metaphor List.University of California. Berkley: 1991.

MCGLONE 2007: MCGLONE, Matthew. What is the explanatory value of a conceptual metaphor?. Language \& Communication 27(2). 2007.

MRŠEVIĆ-RADOVIĆ 1987: MRŠEVIĆ-RADOVIĆ, Dragana. Frazeološke glagolsko-imeničke sintagme u savremenom srpskohrvatskom jeziku. Filološki fakultet. Beograd: 1987. [orig] МРШЕВИЋ-РАДОВИЋ, Драгана. Фразеолошке глаголско-именичке синтагме у савременом српскохрватском језику. Филолошки факултет. Београд: 1987.

OUKLI 2007: OAKLEY, Todd. Image Schemas. In D. Geeraerts and H. Cyckens (Eds.), The Oxford Handbook of Cognitive Linguistics (pp. 214-235). Oxford: 
Oxford University Press: 2007.

STANOJEVIĆ 2009: STANOJEVIĆ, Mateusz-Milan. Konceptualna metafora u kognitivnoj lingvistici: pregled pojmova. Suvremena lingvistika, god. 68, br. 2 . Zagreb: 2009.

DŽONSON 1987: JOHNSON, Mark. The Body in the Mind: The Bodily Basis of Meaning, Imagination, and Reason. Chicago and London: The University of Chicago Press. 1987.

\section{Извори}

RMS 2011: Rečnik srpskog književnog jezika. Matica srpska. Novi Sad: 2011. [orig] РМС, Речник српског књижевног језика. Матица српска. Нови Сад: 2011.

REČNIK SANU 2017: Rečnik srpskohrvatskog književnog jezika. Institut SANU. Beograd: 2017. [orig] РЕЧНИК САНУ, Речник српскохрватског книжевног језика. Институт САНУ. Београд: 2017.

SLOVAR RUSKOGO JAZIKA 2010: Oniks, Mir i obrazovanie. Moskva: 2010. [orig] Словарь русского языка 2010. Оникс, Мир и образование. Москва: 2010.

FRAZEOLOŠKI REČNIK SRPSKOG JEZIKA 2012: Izdavačka kuća Prometej. Beograd: 2012. [orig] Фразеолошки речник српског језика 2012. Издавачка кућа Прометеј. Београд: 2012.

FRAZEOLOGIČESKI SLOVAR RUSKOGO JAZIKA 2014: Adelant. Moskva: 2014. [orig] Фразеологический словарь русского языка. Аделант. Москва: 2014.

Oxford Dictionary of Idioms, Second Edition. (2004). Oxford: Oxford University Press.

Oxford English Dictionary. Second edition. (1989). Oxford: Oxford University Press. Sophia Lubensky, Russian-English Dictionary of Idioms, Revised Edition, 2014, Yale University Press. 
Эмилия Йович

\section{РОЛЬ КОНЦЕПТУАЛЬНОЙ МЕТАФОРЫ ПУТЕШЕСТВИЯ В ФРАЗЕОЛО- ГИЗАЦИИ ЛЕКСЕМЫ ПУТЬ НА ПЛАНЕ РУССКОГО, СЕРБСКОГО И АН- ГЛИЙСКОГО ЯЗЫКОВ}

В данной статье исследуются основные принципы построения концепғ туальной метафоры ПУТЕШЕСТВИЯ на материале лексемы путь, входящей в состав фразеологизмов русского, сербского и английского языков. Целью нашего исследования является определение сходств и различий анализируемых метафорических выражений на всех трех языках. Теория концептуальной метафоры и изобразительных схем послужила нам теоретической основой, в то время как методологически мы полагаемся на контрастный метод анализа. Исходя из предположения, что концептуализация понятия путь очень похожа в изучаемых языках, мы обнаружили, что наибольшее количество выделенных фразеологизмов во всех трех языках находится в корреспондентных или эквивалентных отношениях.

Ключевые слова: фразеологизмы, концептуальная метафора, путь, изобразительные схемы, фразеологическая картина мира, концептуальный анализ 